\title{
Mesocosm Experiments at a Tunnelling Construction Site for Assessing Re-Use of Spoil Material as a By-Product
}

\author{
Anna Barra Caracciolo ${ }^{1} \mathbb{C}$, Paola Grenni ${ }^{1, *}{ }^{\mathbb{D}}$, Livia Mariani ${ }^{1}$, Jasmin Rauseo ${ }^{2}$, Martina Di Lenola ${ }^{1}$, \\ Valerio Giorgio Muzzini ${ }^{3}$, Enrica Donati ${ }^{4}{ }^{\circ}$, Ines Lacchetti ${ }^{5}$, Paola Margherita Bianca Gucci ${ }^{5}$, Antonio Finizio ${ }^{1,6}$, \\ Eleonora Beccaloni ${ }^{5}$ and Luisa Patrolecco ${ }^{2}$ (D) \\ 1 Water Research Institute, National Research Council (CNR-IRSA), 00010 Rome, Italy; \\ barracaracciolo@irsa.cnr.it (A.B.C.); 1.mariani@irsa.cnr.it (L.M.); dilenola@irsa.cnr.it (M.D.L.); \\ antonio.finizio@unimib.it (A.F.) \\ 2 Institute of Polar Sciences, National Research Council (CNR-ISP), 00010 Rome, Italy; \\ jasmin.rauseo@cnr.it (J.R.); luisa.patrolecco@cnr.it (L.P.) \\ 3 Institute of Research on Terrestrial Ecosystems, National Research Council (IRET-CNR), 00010 Rome, Italy; \\ valeriogiorgio.muzzini@cnr.it \\ 4 Institute for Biological Systems, National Research Council (ISB-CNR), 00010 Rome, Italy; enrica.donati@cnr.it \\ 5 Environmental and Health Department, Italian Institute of Health (ISS), 00161 Rome, Italy; \\ ines.lacchetti@iss.it (I.L.); paola.gucci@iss.it (P.M.B.G.); eleonora.beccaloni@iss.it (E.B.) \\ 6 Earth and Environmental Sciences Department, University of Milano Bicocca, 20126 Milano, Italy \\ * Correspondence: grenni@irsa.cnr.it
}

check for updates

Citation: Barra Caracciolo, A.; Grenni, P.; Mariani, L.; Rauseo, J.;

Di Lenola, M.; Muzzini, V.G.; Donati,

E.; Lacchetti, I.; Gucci, P.M.B.; Finizio,

A.; et al. Mesocosm Experiments at a Tunnelling Construction Site for Assessing Re-Use of Spoil Material as a By-Product. Water 2021, 13, 161. https:/ / doi.org/10.3390/w13020161

Received: 10 November 2020

Accepted: 8 January 2021

Published: 12 January 2021

Publisher's Note: MDPI stays neutral with regard to jurisdictional clai$\mathrm{ms}$ in published maps and institutional affiliations.

Copyright: (C) 2021 by the authors. Licensee MDPI, Basel, Switzerland. This article is an open access article distributed under the terms and conditions of the Creative Commons Attribution (CC BY) license (https:// creativecommons.org/licenses/by/ $4.0 /)$.

\begin{abstract}
Mechanized excavation of tunnels with Earth Pressure Balance-Tunnel Boring Machines requires the use of foaming agents. The latter contain the anionic surfactant sodium lauryl ether sulphate (SLES) as the main compound. The re-use as a by-product of excavated soil containing foaming agents (spoil material) can pose a risk for soil and particularly for aquatic ecosystems if they are close to the spoil material final destination site. This work reports the chemical results (SLES residual concentrations) and ecotoxicological effects (battery of five tests) of 28 day-mesocosm studies performed at a tunnelling construction site. The soil mesocosms were set up with two different lithologies, which contained four different foaming agent products at the highest amounts used for excavation. The decrease in SLES concentrations and the ecotoxicological tests were performed in soil and its water extract (elutriate) at different times $(0,7,14,28 \mathrm{~d})$. Elutriates were prepared in order to simulate a possible SLES leaching from soil to water. The results showed a decrease in SLES over time and different ecotoxicological responses depending not only on the initial amount of each product, but also on the soil lithology and organism tested (aquatic or terrestrial). This study showed how only site-specific ecotoxicological evaluations can ensure a safe management of the spoil material, making possible the re-use of soil and avoiding production of waste.
\end{abstract}

Keywords: SLES; environmental compatibility; site-specific protocol; Vibrio fischeri; Danio rerio; Eisenia fetida; Lepidium sativum; toxicity test battery integrated index

\section{Introduction}

The use of millions of tons of excavated soil (spoil material) as a by-product can be a unique opportunity for recycling a useful resource for various purposes, in line with the circular economy [1-3]. It is handled in different ways worldwide. At the EU level, specific guidelines for excavated material management are contained in the Waste Framework Directive 2008/98/EC [4,5]. The latter describes the technical characteristics required for spoil material re-use/recycling, considering both environmental protection and the costs of treatment or use as a virgin raw material.

Some recent publications have posed the question of the re-use of spoil material from mechanized tunnelling [6-12], since high amounts are produced at each excavation site. They highlighted that the final destination of this material needs to be considered with care, 
in particular to protect the water compartment. This aspect is not always considered in the framework of spoil material handling at a European level [4,5]. Worksite management of spoil material has to be performed in major construction projects [13] in accordance with the national legislations (e.g., Italian Decrees 161/2012 and 120/2017 [14,15]). For example, the addition of lime (1-6\% in weight) can be a practical procedure for the chemical stabilization of excavated material (usually for clayey and silty soils) [7]. It produces shortterm modifications (flocculation and agglomeration of clay minerals, reducing plasticity and moisture content) and a long-term reaction resulting in stabilization of the material, cementing and increasing its strength [7]. Moreover, the storage of spoil material in temporary deposit areas for several days before its final use can also be useful for ensuring soil drying and degradation of any chemicals (e.g., those contained in foaming agents) used for soil conditioning during tunnelling $[16,17]$.

The use of commercial products (foaming agents) is necessary in mechanized tunnelling with Earth Pressure Balance-Tunnel Boring Machines (EPB-TBMs) [18-22]. The spoil material coming out of the machine can be maintained at temporary deposits. If, at this point, a set of analyses demonstrates its environmental compatibility, it can be transferred to the final destination site and used as a by-product $[23,24]$. Currently, there are thresholds for organic and inorganic contaminants (e.g., heavy metals and hydrocarbons with more than 12 carbon atoms) in Italian regulations (Decrees No. 152/2006 and No. $120 / 2017)$, but there is no threshold limit for SLES in excavated material in either European or Italian legislation.

Several foaming agents contain anionic surfactants (e.g., alkyl ether sulphates and sodium lauryl ether sulphate-SLES) as their main components, ranging from 5 to $50 \%[23,25]$. Recent studies found SLES to be a biodegradable compound in spoil material $[17,23,25]$, and a bacterial consortium able to degrade SLES was recently selected [26], although it can be toxic for aquatic organisms if residual concentrations persist [16,27-32]. In order to exclude any possible environmental ecotoxicological effects from excavated soil produced during tunnel construction, the Italian Ministry of Environment requires a site-specific technical report, which has to demonstrate that the spoil material at the final destination site does not pose any risk for soil and aquatic ecosystems $[16,29,30]$. In this respect, this work reports a site-specific experimental study performed at a construction site using mesocosms containing soil conditioned with four different foaming agents at the maximum treatment ratios (TR, litres of foam per $\mathrm{m}^{3}$ of soil) suggested for this type of tunnelling. Analytical determination of SLES in soil and their water extracts (elutriates), and five ecotoxicological tests were performed from the start of the mesocosm experiment and over 28 days. An initial pre-screening of the four products using Vibrio fischeri as the test organism was carried out (effective concentrations producing a $20 \%$ or $50 \%$ change in the endpoint response, $\mathrm{EC}_{20}$ and $\mathrm{EC}_{50}$ ). In some mesocosms the presence/absence of lime was also tested. At the same time, residual concentrations of SLES were analysed in soil samples and in water extracts. The mesocosm experiment was performed by simulating the spoil material storage at the construction site in a scenario as close as possible to the real situation where natural SLES biodegradation can occur. On the basis of the overall chemical and ecotoxicological results, a site-specific protocol to be applied during the excavation of this tunnel was drawn up. The various steps in the mesocosm experiment, the variation of SLES concentration in the soil and elutriates over time and the corresponding ecotoxicological response were evaluated, discussed and summarized in a toxicity test battery integrated index.

\section{Materials and Methods}

\subsection{Soils and Foaming Agents}

The construction site was in the Apennines of Central Italy and involved a tunnel of about $7.5 \mathrm{~km}$ for a three-lane highway. The biggest EPB-TBM ever used so far in Europe, with a diameter of $15.87 \mathrm{~m}$, was employed. The overall excavated material to be managed as a safe by-product was estimated at about 1.5 million $\mathrm{m}^{3}$. Two soil types (MON: gravel 
in a sandy-silty soil; density: $1930 \mathrm{~kg} / \mathrm{m}^{3}$; SIL: gravel in a sandy-silty-clay soil; density: $1750 \mathrm{~kg} / \mathrm{m}^{3}$ ) were identified as representative of the extreme lithologies faced during the tunnel excavation. The soils to set up the mesocosm study were collected at around $50 \mathrm{~m}$ below ground. Aliquots of SIL and MON soils were analysed to determine the microbial abundance and organic carbon (OC) content, following methods described in previous works [23].

Four foaming agent products (P1, P2, P3 and P4, equally suitable from a geotechnical point of view for this tunnel excavation) to be used for the two lithologies were suggested by the geotechnical laboratory feasibility studies with slump cone tests. These tests evaluated the workability and consistency of the two soils with the various foaming agents, providing the correct foaming agent treatment ratio (TR) to be applied for each soil [19-21,33]. The tests were conducted at Turin Polytechnic (Environment, Land and Infrastructure Engineering Dept., Tunnelling and Underground Space Lab), using a foam generation system that reproduces the conditioning characteristics used by an EPB-TBM [19,34]. Table 1 reports the density of each foaming agent and the highest amount used (soil Treatment Ratio, TR, $\mathrm{L} / \mathrm{m}^{3}$ ) [19], together with the percentage of SLES. For the SIL lithology, in one case P3 was used together with P4 to improve the soil workability [18].

Table 1. Foaming agent products $(\mathrm{P})$ and their relative amount used for the soil conditioning. The product density, main components, CAS\#, EC\# and component \% are those reported in the chemical safety data sheets of the commercial products. P4 was used together with P3. SIL: sandy-silty-clay soil; MON: gravel in a sandy-silty soil. The foaming agent amount to be applied in each soil (TR: soil Treatment Ratio) was assessed by slump conic tests.

\begin{tabular}{|c|c|c|c|c|c|}
\hline \multirow{2}{*}{ Product } & \multirow{2}{*}{$\begin{array}{l}\text { Density } \\
\left(\mathrm{g} / \mathrm{cm}^{3}\right)\end{array}$} & \multirow{2}{*}{ Main Components, CAS\# and EC\# } & \multirow{2}{*}{ Component \% } & \multicolumn{2}{|c|}{$\mathrm{TR}\left(\mathrm{L} / \mathrm{m}^{3}\right)$} \\
\hline & & & & SIL & MON \\
\hline $\mathrm{P} 1$ & $\sim 1$ & $\begin{array}{l}\text { Sodium lauryl ether sulphate (SLES) } \\
\text { 9004-82-4; 618-398-5 }\end{array}$ & $10-30$ & 0.53 & 1.46 \\
\hline $\mathrm{P} 2$ & $1.35-1.45$ & $\begin{array}{c}\text { Alcohols, C12-14, ethoxylated, sulphates, } \\
\text { sodium salts (SLES) } \\
68891-38-3 ; 500-234-8\end{array}$ & $10-50$ & 0.35 & 1.2 \\
\hline \multirow[t]{2}{*}{ P3 } & \multirow[t]{2}{*}{1.04} & $\begin{array}{l}\text { (a) Alcohols, C12-14, ethoxylated, sulphates, } \\
\text { sodium salts (SLES) } \\
68891-38-3 ; 500-234-8\end{array}$ & $10-20$ & 0.59 & \multirow[t]{2}{*}{1.46} \\
\hline & & $\begin{array}{c}\text { (b) 1,2-benzisotiazol-3(2H)-one } \\
\text { 2634-33-5; 220-120-9 }\end{array}$ & $0.005-0.01$ & 0.44 * & \\
\hline $\mathrm{P} 4^{* *}$ & 1.04 & $\begin{array}{l}\text { Alcohols, C12-14, ethoxylated, sulphates, } \\
\text { sodium salts (SLES) } \\
68891-38-3 ; 500-234-8\end{array}$ & $25-30$ & 0.165 & - \\
\hline
\end{tabular}

* If P3 is used with P4; in this case P3 is used with a less TR value, ${ }^{* *} \mathrm{P} 4$ in this study is used only in addition to P3 foaming agent.

\subsection{Soil Mesocosm Set-Up at the Construction Site}

Each mesocosm $\left(1 \mathrm{~m}^{3}\right.$, performed in duplicate) consisted of a concrete storage tank containing the soil (SIL or MON) treated with the various foaming agents, as reported in Table 2. Lime was added at $20 \mathrm{~kg} / \mathrm{m}^{3}$ in some SIL mesocosms. Lime can be added to chemically stabilize fine texture soils and in this case was used only for SIL. A total of eleven experimental conditions were set up. Each mesocosm was maintained at the tunnel construction site (Central Italy, $270 \mathrm{~m}$ altitude, April-May 2016) under real conditions (e.g., temperature, humidity) for 28 days in a shed with open sides to protect the soil from any rain, simulating temporarily depositing the spoil material. The air temperature was monitored daily. 
Table 2. Summary of the 11 experimental conditions (soil mesocosms) at the construction site.

\begin{tabular}{cccc}
\hline Soil Lithology & Foaming Agent & Lime & Mesocosm Acronym \\
\hline & P1 & - & SIL + P1 \\
P2 & - & SIL + P2 \\
SIL & P3 & - & SIL + P3 \\
& P3 and P4 & - & SIL + P3 + P4 \\
& P3 & Yes & SIL + P3 + L \\
& - & - & SIL \\
MON & P1 & Yes & SIL L \\
& P2 & - & MON + P1 \\
& P3 & - & MON + P2 \\
& - & - & MON \\
\hline
\end{tabular}

At fixed times ( $0,7,14,28$ days), soil samples (about $20 \mathrm{~kg}$ from each mesocosm) were collected with a soil probe equipped with an auger and a small shovel (deep: $20-100 \mathrm{~cm}$ ), mixed, transported to the lab in refrigerated bags and then used for the different analyses or ecotoxicological tests.

At each sampling and for each condition, SLES residual concentration and ecotoxicological tests were performed on the elutriates. Moreover, the soil water holding capacity (WHC) was measured at the start of the experiment and soil temperature, moisture and $\mathrm{pH}$ were monitored over time. WHC was determined following the ISO method 11274:2019 (Soil quality determination of water retention characteristics-laboratory methods). The $\mathrm{pH}$ was measured using a portable $\mathrm{pH}$ meter (HI 9124, Hanna Instruments) in a 1:2.5 soil-water suspension.

Elutriates were prepared in a solid/liquid ratio of 1:10 with distilled water (taking the soil moisture of the sample into account), following standardized procedures for waste characterization (UNI EN 12457-2:2004 [35]) with some modifications. In brief, each soil sample (3 replicates, $100 \mathrm{~g}$ each) was put into a bottle $(1 \mathrm{~L})$ with distilled water and shaken (130 rpm for $24 \mathrm{~h}$ at $20^{\circ} \mathrm{C}$, in the dark), simulating the soil leaching process. Further details are reported in Grenni et al. [17] and Mariani et al. [16]. After the solid particles fell to the bottom $(15 \mathrm{~min})$, the supernatant was centrifuged $(15 \mathrm{~min}$ at $9000 \mathrm{rpm})$. The elutriates obtained were directly used for SLES determination or filtered $(0.45 \mu \mathrm{m}$, cellulose acetate Whatman) for ecotoxicological analyses as reported in UNI EN 14735:2005 (Characterization of waste-preparation of waste samples for ecotoxicity tests).

\subsection{Chemicals and SLES Analyses}

All solvents utilised for chemical determinations were of HPLC grade and were obtained from VWR (Radnor, PA, USA). SLES of technical grade purity was purchased from BOC Sciences (New York, NY, USA) and used as the reference compound for the anionic surfactant analytical determinations. SLES was extracted from soil and its water extracts following the method reported in Grenni et al. [17]. Briefly, the target compound was extracted from fresh soil samples (about $2 \mathrm{~g}$ ) using Pressurized Liquid Extraction (PLE, Dionex ASE 150, Thermo Fisher Scientific Inc., Waltham, MA, USA) followed by the liquid-liquid MBAS extraction method (Methylene Blue Active Substances [36]).

As regards the elutriates SLES was directly measured using the MBAS method. The absorbance of the blue SLES-MBAS complex, obtained both from soil (PLE extracts) and elutriate samples, was then measured by spectrophotometry at $650 \mathrm{~nm}$ wavelength (PerkinElmer Lambda 25 UV-VIS spectrophotometer). Finally, the analytical SLES concentration was calculated using the equations resulting from the standard calibration curves (0.05-4 mg/L SLES), previously determined, as detailed in Barra Caracciolo et al. [23]. The limit of detection (LOD), calculated in accordance with the IUPAC method [37], was $0.013 \mathrm{mg} / \mathrm{L}$ and the PLE extraction recovery was $96.5 \pm 1.6 \%$. 


\subsection{Ecotoxicological Tests}

A pre-screening of the foaming agent products ( $\mathrm{P} 1, \mathrm{P} 2, \mathrm{P} 3, \mathrm{P} 4$ and the combination of $\mathrm{P} 3$ and $\mathrm{P} 4$, see Table 1) was initially performed to evaluate their intrinsic ecotoxicity. For this purpose, the toxic effective concentration ( $\mathrm{EC}_{20}$ and $\mathrm{EC}_{50}$ values) of the products was evaluated with the bacterium Vibrio fischeri.

In the mesocosm experiment the ecotoxicity of all soil samples or soil water extracts was evaluated at different times $(0,7,14$ and $28 \mathrm{~d})$ from the conditioning using the Vibrio fischeri toxicity test, Lepidium sativum seed germination and seedling growth tests, Eisenia fetida tests and the Danio rerio test [38]. All tests were conducted in at least three replicates. Positive and negative controls were also considered in accordance with the specific guidelines. All data are reported as the effect percentage (\%) in the soil (SIL or MON) (net of any possible intrinsic toxicity measured in the untreated soils) or in the corresponding water extracts.

\subsubsection{Vibrio fischeri Acute Toxicity Test}

The Vibrio fischeri acute toxicity test (UNI EN ISO 11348-3:2019 [39]), was performed using a Microtox ${ }^{\circledR}$ analyser (Model 500, Modern Water, London, UK), in accordance with both the ISO and the manufacturer instructions. The test endpoint is the luminescence inhibition of the Vibrio fischeri bacterium in contact with a chemical substance or environmental samples at three exposure times $(5,15$ and $30 \mathrm{~min})$. The measurements are compared with a negative control (a bacterial suspension in a solution containing $2 \% \mathrm{NaCl}$ in distilled water). Freeze-dried and lyophilized V. fischeri (strain NRRL B-11177) and Reconstitution Solution (used for rehydrating the bacteria) were purchased from Ecotox LDS s.r.l. (Milan, Italy). The saline solution $(2 \% w / v \mathrm{NaCl})$ and the osmotic adjustment solution $(22 \% w / v$ $\mathrm{NaCl}$, used to obtain about $2 \%$ of salinity in the samples) were prepared with Milli-Q water. The toxicant reference 3,5-dichlorophenol was used as the positive control.

The $V$. fischeri test $(81.9 \%$ Basic Test [39]) was first used to evaluate the intrinsic toxicity of the four foaming agents (P1, P2, P3, P4 and P3 + P4; see Table 1) in terms of concentrations capable of causing luminescence inhibitions of $20 \%\left(\mathrm{EC}_{20}\right)$ and $50 \%\left(\mathrm{EC}_{50}\right)$, respectively. Stock solutions of the four foaming agent products $(258.5 ; 261.0 ; 255.3 ; 261.8$ $\mathrm{mg}$ product/L for P1, P2, P3 and P4, respectively) were prepared with distilled water to produce 7 dilutions $(2.6 ; 5.2 ; 13.1 ; 26.2 ; 52.4 ; 104.7 ; 212.1 \mathrm{mg}$ product/L) to be tested for each commercial product. Three tests were performed for each foaming agent and the EC values were calculated using the Microtox software (MicrotoxOmni Software, version 4.2; Modern Water, London, UK).

The $V$. fischeri test $(81.9 \%$ Screening Test [39]) was then used to evaluate the acute toxicity of soil water extracts (elutriates) over the 28-day mesocosm experiment in all conditions. Before the tests, the salinity (adjusted to $2 \%$ with the osmotic solution) and $\mathrm{pH}$ (corrected up to the 6.0-8.0 range) of each elutriate were adjusted in line with the ISO protocol. The results are reported as the inhibition percentage (\%), calculated using the Microtox software, after 30 min exposure of bacteria to the samples. According to the UNI EN ISO 11348-3:2019 protocol, luminescent inhibition $\geq 20 \%$ is considered a toxic effect, compared to the negative control $[40,41]$ and as a validity criterion the coefficient of variation $(\mathrm{CV} \%)$ between replicate results has to be $<20 \%$.

\subsubsection{Lepidium sativum Seed Germination and Seedling Growth Tests}

The phytotoxicity was tested with the seed germination, seedling emergence and early growth tests performed with Lepidium sativum seeds (Fratelli Ingegnoli, Milano). For the germination test, seeds (10 seeds, in triplicate) were exposed to the elutriates in accordance with the US EPA Guidelines [42]. The test evaluates if the water extracts have any effect, expressed as the Germination Index (GI\%), on germination and lengthening of the roots, hypocotyls and epicotyls of plants [42]. The test was performed in Petri plates (diameter $90 \mathrm{~mm}$ ) with a paper disk soaked with $5 \mathrm{~mL}$ of elutriate or distilled water (negative control). The seeds were put in contact with the elutriates for $72 \mathrm{~h}$ in a growth chamber at $25^{\circ} \mathrm{C}$ 
in the dark. The germinated seeds were then counted and the lengths of the different parts of each young seedling were measured to calculate the GI\% [43], as reported in Grenni et al. [17]. A test is considered toxic if the GI $<80 \%$ [44].

The seedling growth test $[42,43]$ was performed using pots containing soil samples (about $3 \mathrm{~kg}$, three replicates) of the various conditioned soils, where 20 seeds of L. sativum were sown. Water was added to reach $70 \%$ of soil water capacity. The soil moisture was kept constant by daily weighing the pots, which were kept in a greenhouse $\left(25^{\circ} \mathrm{C} \pm 10^{\circ} \mathrm{C}\right.$; photoperiod: $16 \mathrm{~h}$ light $/ 8 \mathrm{~h}$ dark: air humidity: $70 \% \pm 25 \%$; light intensity: $350 \pm 50 \mu \mathrm{E} / \mathrm{m}^{2} / \mathrm{s}$ ). An OECD soil (sandy-clay soil; total C: $1.46 \%$, total N: $448 \mathrm{mg} / \mathrm{kg}, \mathrm{P}: 110 \mathrm{mg} / \mathrm{kg}$, K: $157 \mathrm{mg} / \mathrm{kg}$ of and $\mathrm{Mg}: 95 \mathrm{mg} / \mathrm{kg}$ ) was also used as the negative control. After a $21 \mathrm{~d}$ exposure period, the plants were counted and their aerial parts used to measure the dry biomass $\left(105^{\circ} \mathrm{C}\right.$ for $48 \mathrm{~h}$ ). The biomass values were compared with those of plants grown in the negative control. The results are expressed as the Growth Index (GrI, \%) [45] compared to the growth of the plants in the soils without foaming treatment.

\subsubsection{Eisenia fetida Acute and Chronic Tests}

The earthworm acute toxicity test was conducted in line with the filter paper contact test (OECD guideline 207 [44]), using elutriates (10 replicates) obtained from the soils at each experimental time. Specimens of E. fetida were purchased from a commercial earthworm breeding farm (Con.It.A.Lo., Turin, Italy). Before the tests, the organisms were maintained for $3 \mathrm{~h}$ in the dark on a wet filter paper to evacuate the earthworms' gut content, washed with tap water and then dried carefully with an absorbent paper. The test was performed at $20^{\circ} \mathrm{C} \pm 2{ }^{\circ} \mathrm{C}$, in the dark. The ecotoxicological endpoint (earthworm mortality) was assessed after $48 \mathrm{~h}$. The test involved the elutriates $(1 \mathrm{~mL})$ and one mature earthworm for each glass vial $(8 \times 3 \mathrm{~cm}$ diameter, flat-bottomed), on the walls and bottom of which a filter paper $\left(80-85 \mathrm{~g} / \mathrm{m}^{2}, 0.2 \mathrm{~mm}\right.$ thickness) was placed. All vials were closed with a stopper with small ventilation holes. The $\mathrm{pH}$ of the elutriates to be tested was measured in all cases. Distilled water $(1 \mathrm{~mL})$ was added to the negative controls. The results are expressed as mortality (\%).

The chronic earthworm toxicity test (28 days of organism exposure) was performed according to OECD Guideline N. 222 [46], using soil samples obtained from each experimental condition (conditioned soils with foaming agents or non-conditioned soils) taken at 0 and 7 days. In addition, an artificial soil prepared according to OECD Guideline No. 207 [47] was used as the negative control to fulfil the validity criteria (mortality $<10 \%$ ). Before the tests, the organisms were acclimated for 7 days, washed with tap water and put on a filter paper to remove any excess of water. For each test (three replicates), 10 E. fetida adults with a clitellum (2 months-1 year-old; weight: $260-600 \mathrm{mg}$ ) were put in closed glass boxes filled with about $700 \mathrm{~g}$ of soil samples and incubated at $20^{\circ} \mathrm{C}$ (photoperiod: $16 \mathrm{~h}$ light/ $8 \mathrm{~h}$ dark; $400-800$ lux). The boxes were opened once a week. The three endpoints tested were mortality and growth (at 28 days) and reproduction (at 56 days). In particular, after the 28 days of organism exposure required by the OECD test, the live worms were counted and any behavioural or morphological changes recorded, whereas after 56 days reproduction was assessed by counting the juvenile earthworms, hatched and unhatched cocoons, and any damage to the organisms was recorded.

\subsubsection{Danio rerio Acute Toxicity Test}

The Fish Embryo Acute Toxicity (FET) test was performed in accordance with OECD Guideline No. 236 [48]. This test uses newly fertilised zebrafish (Danio rerio) [49,50] eggs exposed for $96 \mathrm{~h}$ to a liquid sample and is intended to reflect acute toxicity in fish in general $[17,51,52]$. Fertilised eggs were obtained from a breeding stock of zebrafish adults maintained in aquariums and fed 3-4 times a day with a combination of dried food and newly hatched Artemia salina shrimps, in line with the OECD guideline recommendations. The eggs were collected with an egg-trap, made of a glass vessel covered with a mesh submerged in the aquarium. Randomly selected embryos (twice the number needed for 
each test) were transferred into Petri dishes and observed with an inverted microscope to select only those developing between the 4- and 32-cell stages and with an intact chorion. A 3,4-dichloroaniline (4 mg/L) solution was used as the positive control.

Each test was performed with 24-well plates containing 20 embryos per sample ( $2 \mathrm{~mL}$ of elutriate) and 4 embryos as internal negative controls, which were incubated at $26.0 \pm 1.0^{\circ} \mathrm{C}$ for $96 \mathrm{~h}$ (photocycle: $14: 10 \mathrm{~h}$ light/dark). Four endpoints were used as fish lethality indicators: fertilised egg coagulation, lack of somite formation, non-detachment of the tail and lack of heartbeat [53]. They were measured every $24 \mathrm{~h}$, up to the end of the exposure period $(96 \mathrm{~h}$ ). The acute toxicity effect was evaluated as a positive result in each of the four endpoints [54]. The results are expressed as mortality (\%). The ecotoxic threshold limit is mortality $>20 \%$.

\subsection{Toxicity Test Battery Integrated Index}

The results obtained from each individual test can sometimes give different responses to a specific toxicant or contaminated environmental matrix due to the different sensitivity of each organism tested with the specific chemical.

The use of a toxicity integrated index can overcome this issue by combining the overall results, as suggested by the Guidelines of the Italian National Institute for Environmental Protection and Research (ISPRA) [55] and verified in other studies [17]. An integrated index can be applied to any ecotoxicological test series, no matter what the endpoint number and type. It calculates the overall toxicity and the possible risks in a sample, on a toxicity scale from 0 to $100 \%$ [17,56,57]. In this study, the ecotoxicological results obtained from each individual test at 0 and 7 days of the mesocosm experiment were combined in the battery index. This choice was made because the various toxic responses were essentially unvaried 7 days after the start of the experiment. The algorithm, described in detail in Grenni et al. [17], required at least three endpoints and the results reported here are expressed as a toxicity integrated index $(\mathrm{T} \%)$. Severity, variability and response are specific for each bioassay, whereas the number of endpoints measured and consistency were the same for all sampling times. Outputs of the Integrated Battery Index can vary from 0 to $100 \%$ and the corresponding hazard classes are classified from negligible to very high.

\subsection{Statistical Analysis}

Differences in SLES concentrations between the various conditions were analysed using the Kruskal-Wallis One Way ANOVA (analysis of variance) on Ranks. The post-hoc test used for finding differences between groups was the Tukey test (Sigma Stat 3.5-DUNDAS Software LTD). Correlations between variables (e.g., SLES residual concentrations versus ecotoxicological data) were calculated using MS Excel 2013.

\section{Results}

\subsection{Pre-Screening of the Four Foaming Agents with V. fischeri}

The dose-response relationships between the various concentrations tested $(\mathrm{mg} / \mathrm{L})$ of each foaming agent and the effect (expressed as \% bioluminescence inhibition) on the bacterium $V$. fischeri were calculated with the Microtox software. The data made it possible to calculate the effective concentrations of the foaming agent products (P1, P2, P4 and P3+ P4) causing $20 \%\left(\mathrm{EC}_{20}\right)$ or $50 \%\left(\mathrm{EC}_{50}\right)$ of bacterial luminescence inhibition (Table 3$)$.

The $\mathrm{EC}_{20}$ and $\mathrm{EC}_{50}$ values for the $\mathrm{P} 3$ product refer to those reported in a recent paper [16]. The highest $\mathrm{EC}_{20}(5.75 \mathrm{mg} / \mathrm{L})$ and $\mathrm{EC}_{50}(17.86 \mathrm{~g} / \mathrm{L})$ values were found for P3, demonstrating it was less toxic than the others. Since P1 and P2 showed similar toxicity and were lower than P4, they were also selected for the subsequent mesocosm experiments. 
Table 3. Toxicity of the four foaming agent products (P1, P2, P3, P4 and P3 + P4) evaluated by the $V$. fischeri test; results are expressed as $\mathrm{EC}_{20}$ and $\mathrm{EC}_{50} \pm$ standard errors (s.e.) at $30 \mathrm{~min}$ of exposure.

\begin{tabular}{ccccc}
\hline Product & $\mathrm{EC}_{\mathbf{2 0}}(\mathbf{m g} / \mathbf{L})$ & s.e. & EC $_{\mathbf{5 0}}(\mathbf{m g} / \mathbf{L})$ & s.e. \\
\hline P1 & 2.21 & 0.29 & 6.97 & 0.87 \\
P2 & 2.23 & 0.27 & 6.88 & 0.89 \\
P3 & 5.75 & 0.45 & 17.86 & 1.48 \\
P4 & 1.96 & 0.28 & 6.10 & 0.89 \\
P3 + P4 & 4.11 & 0.00 & 12.76 & 0.00 \\
\hline
\end{tabular}

\subsection{Soil Mesocosm Experiment at the Construction Site}

\subsubsection{Organic Carbon and Microbial Abundance, WHC, Soil Moisture, $\mathrm{pH}$, Temperature}

The organic carbon content (OC) was $0.5 \%$ in SIL and $0.3 \%$ in MON and, in line with these values, the microbial abundance was higher $\left(2 \times 10^{6}\right.$ cells $/ g$ soil $)$ in SIL than MON $\left(5 \times 10^{4}\right.$ cells $/ g$ soil $)$.

As regards the maximum water holding capacity ( $\mathrm{WHC}_{\max }$ ) of each soil (SIL or MON) alone or in the presence of lime and the initial moisture of the soils at the mesocosm set-up, the results are reported in Supplementary Materials Table S1. SIL showed a $\mathrm{WHC}_{\max }$ $(33.0 \% \pm 0.8)$ three times higher than MON $(11.4 \% \pm 1.0)$ owing to its fine lithology. Moreover, adding lime further increased the SIL $\mathrm{WHC}_{\max }$. The soil moisture did not significantly decrease during the experimental period (only a slight decrease of $1-4 \%$ was observed).

The soil $\mathrm{pH}$ and the corresponding water extracts, (Supplementary Materials, Table S2) were close to neutral, except for the soils treated with lime, which had, as expected, a basic $\mathrm{pH}$ (about 11).

During the one-month experiment, air temperature changed in line with the season and ranged from $7-12{ }^{\circ} \mathrm{C}$ (daily minimum) to $15-26^{\circ} \mathrm{C}$ (daily maximum). However, the temperature of the soil mesocosms was essentially constant with an average value of $16.8 \pm 0.21^{\circ} \mathrm{C}$ at the sampling depth $(20-100 \mathrm{~cm})$.

\subsubsection{Analytical Determination of SLES in Soils and Elutriates}

SLES residual concentrations measured in soils and elutriates from the mesocosms over time (0, 7, 14 and 28 days) are shown in Figure 1A,B, respectively.

At the start of the experiment (day 0), SLES concentrations found in soils ranged from 77 to $160 \mathrm{mg} / \mathrm{kg}$ for SIL (SIL + P1; SIL + P2; SIL + P3; SIL + P3 + P4; SIL + P3 + L) and from 276 to $648 \mathrm{mg} / \mathrm{kg}$ for MON (MON + P1; MON + P2; MON + P3). These values were in line with the treatment ratios (TRs) applied for the soil conditioning, since the foaming agent amounts were much higher for MON than SIL (Table 1).

SLES concentrations decreased over time in the SIL mesocosms and at 28 days a reduction ranging from $30 \%$ (SIL + P3) to $56 \%$ (SIL + P3 + P4 and SIL + P1) was observed. The SIL + P3-treated soil showed average SLES concentrations significantly lower (ANOVA, $p<0.05)$ than the other conditions.

The initial (0 d) SLES in the elutriates obtained from the SIL mesocosms (Figure 1B) was from a minimum of $1.2 \mathrm{mg} / \mathrm{L}$ for $\mathrm{P} 3$ to a maximum of $4.9 \mathrm{mg} / \mathrm{L}$ for P3 + P4. These values were in line with the corresponding concentrations in soil. In fact, SLES values decreased over time and starting from day 7 all were lower than $1 \mathrm{mg} / \mathrm{L}$.

On the contrary, no significant variation in SLES was found in the MON mesocosms, either in soils (Figure 1A), or in elutriates (Figure 1B). SLES was significantly (ANOVA, $p<0.01$ ) higher in MON than SIL elutriates, with values from 9.6 to $23 \mathrm{mg} / \mathrm{L}$. 


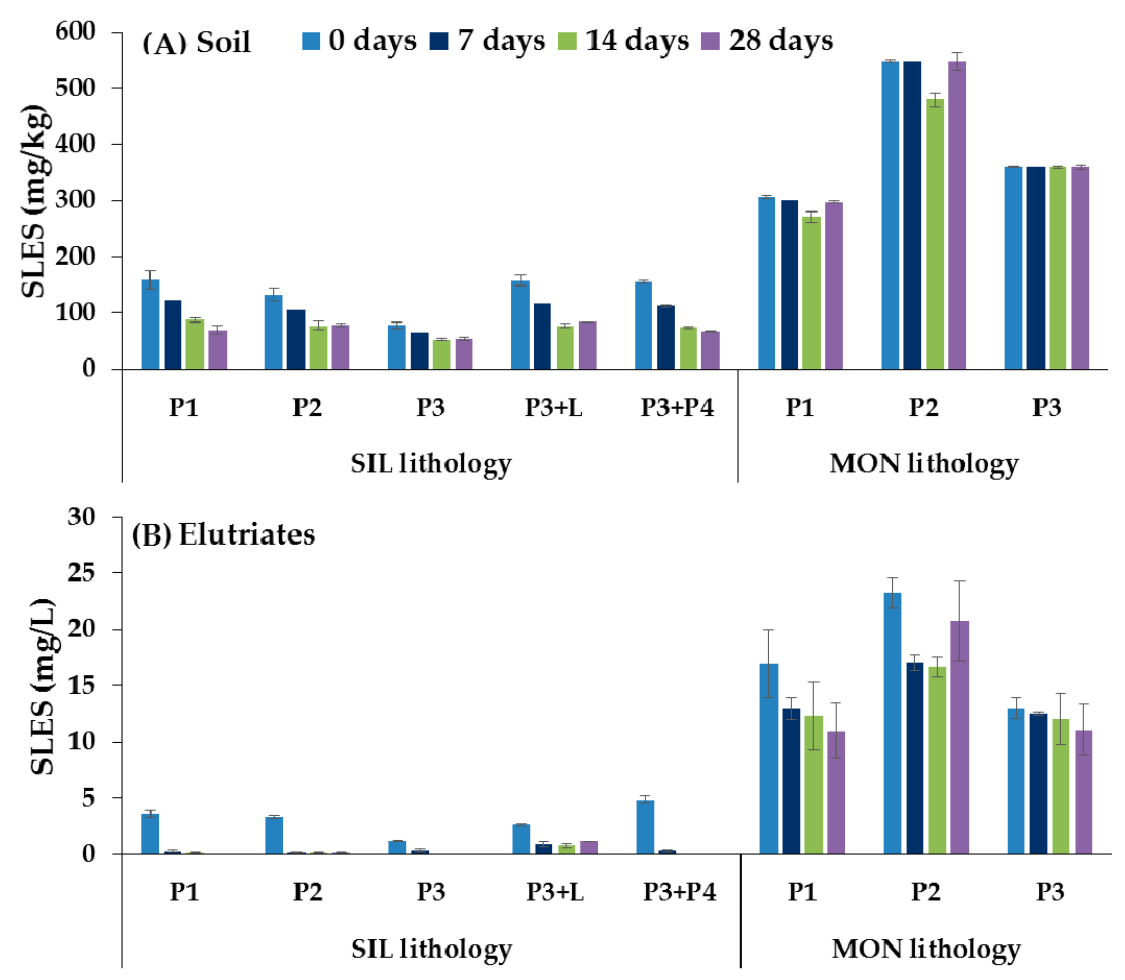

Figure 1. Average values of SLES concentration in the various SIL and MON mesocosm conditions (soils conditioned with $\mathrm{P} 1,2,3,4$ and $\mathrm{P} 3+\mathrm{P} 4)$ at the different sampling times $(0,7,14$ and 28 days). (A) in soil (mg/kg); (B) in elutriates $(\mathrm{mg} / \mathrm{L})$. The vertical bars represent standard errors. SIL: sandysilty-clay soil; MON: gravel in a sandy-silty soil. P1, P2, P3, P4: foaming agent products.

\subsection{Ecotoxicological Tests}

All the ecotoxicological tests ( $V$. fischeri bioluminescence inhibition, L. sativum germination and growth, D. rerio mortality, E. fetida mortality, growth and reproduction) met the validity criteria $[39,46,51,58]$.

The percentages of bioluminescence inhibition (\%) for the bacterium Vibrio fischeri at $30 \mathrm{~min}$ of exposure and at the various experimental times $(0,7,14$ and 28 days) are reported in Figure 2.

An initial bioluminescence inhibition (\%) was observed in all P-treated SIL mesocosms except for SIL + P3 where the effect was lower than the toxicity test threshold of $20 \%$ (Figure 2A).

The highest inhibition $(66 \%)$ was recorded in SIL + P3 + P4 due to the SLES concentration of P4. In any case, the effect was transient and never observed 7 days from the soil conditioning (all values were $<20 \%$ in all samplings). Moreover, a positive correlation $(r=0.9, p<0.01)$ was found between the SLES concentrations in elutriates and their corresponding bioluminescence inhibition values.

The non-treated soils (SIL and MON) did not have any effect on the bioluminescence of the bacterium.

In the case of samples treated with lime (SIL $+\mathrm{L}$ and SIL $+\mathrm{P} 3+\mathrm{L})$, the $\mathrm{pH}$ of the elutriates tested was about 11 and was corrected to neutral, as suggested by the standard protocol, and for this reason no toxicological effect was recorded.

The elutriates produced from the MON P-treated mesocosms (Figure 2B) were toxic over the experimental time, with values ranging from 88 to $95 \%$. 

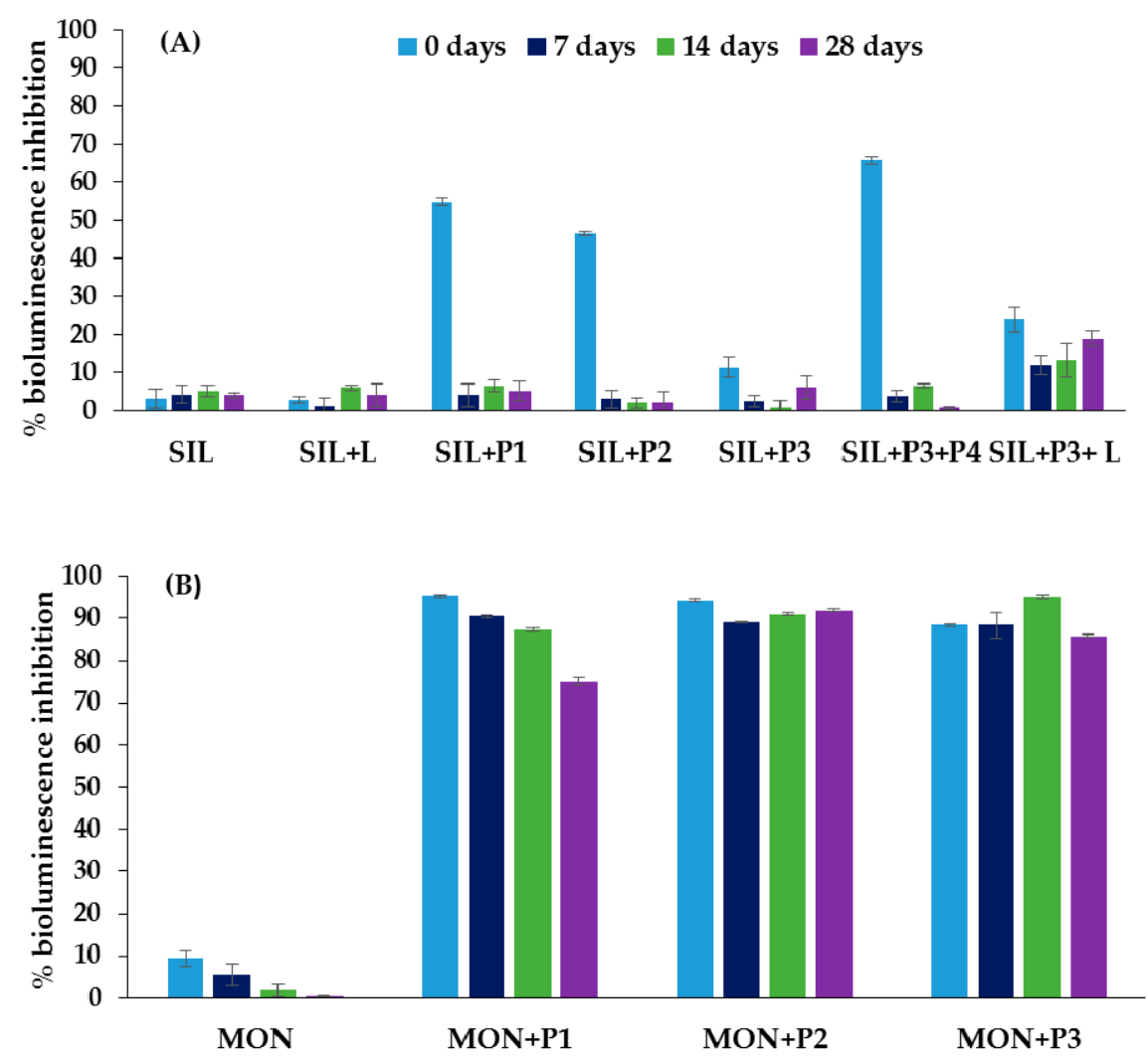

Figure 2. Bioluminescence inhibition (\%) of Vibrio fischeri at $30 \mathrm{~min}$. of exposure to elutriates from (A) SIL and (B) MON mesocosms (conditioned with P1,2,3,4 and P3 + P4) at the various experimental times $(0,7,14$ and 28 days). The vertical bars are the standard errors. SIL: a sandy-silty-clay soil; MON: gravel in a sandy-silty soil. P1, P2, P3, P4: foaming agent products; L: lime.

The results of the L. sativum germination tests, expressed as the Germination index (GI\%), are reported in Table 4. In all conditions, except for SIL + P1 at 0 days, no significant effect on the GI values was observed (values $>80 \%$ ) and in several cases, a positive effect was even recorded.

Table 4. Lepidium sativum Germination index (GI\%) \pm standard errors (s.e.) obtained from elutriates of the various P-conditioned or non-conditioned (SIL or MON) soil mesocosms at different experimental times $(0,7,14$ and 28 days). SIL: sandy-silty-clay soil; MON: gravel in a sandy-silty soil. P1, P2, P3, P4: foaming agent products; L: lime.

\begin{tabular}{ccccccccc}
\hline & \multicolumn{2}{c}{ 0 days } & \multicolumn{2}{c}{ 7 days } & \multicolumn{2}{c}{ 14 days } & \multicolumn{2}{c}{ 28 days } \\
\hline & GI (\%) & s.e. & GI (\%) & s.e. & GI (\%) & s.e. & GI (\%) & s.e. \\
\hline SIL & 131.4 & 13.1 & 96.2 & 24.4 & 130.0 & 8.9 & 181.6 & 10.1 \\
SIL + L & 97.3 & 7.6 & 93.7 & 15.8 & 126.8 & 3.2 & 140.8 & 19.6 \\
SIL + P1 & 55.4 & 5.3 & 89.8 & 11.6 & 105.4 & 11.5 & 146.5 & 35.0 \\
SIL + P2 & 122.2 & 10.9 & 113.0 & 10.1 & 101.1 & 20.3 & 151 & 22.1 \\
SIL + P3 & 117.1 & 32.2 & 136.7 & 4.6 & 120.4 & 3.2 & 168.9 & 8.5 \\
SIL + P3 + P4 & 118.6 & 5.0 & 116.5 & 24.3 & 135.6 & 22.2 & 165.8 & 13.9 \\
SIL + P3 + L & 96.3 & 9.9 & 112.5 & 7.8 & 88.2 & 12.6 & 147.0 & 3.4 \\
\hline MON & 83.3 & 14.2 & 92.5 & 23.4 & 117.6 & 3.0 & 155.6 & 12.3 \\
MON + P1 & 108.8 & 31.5 & 137.7 & 8.9 & 109.9 & 29.1 & 157.4 & 10.7 \\
MON + P2 & 109.3 & 14.2 & 106.9 & 17.0 & 106.1 & 16.2 & 155.2 & 11.4 \\
MON + P3 & 125.7 & 4.3 & 132.6 & 13.7 & 118.5 & 2.5 & 174.2 & 6.7 \\
\hline
\end{tabular}


The results of the $21 \mathrm{~d}$ seedling growth test, expressed as the Growth index (GrI\%), from the soil samples collected from P-conditioned and un-treated mesocosms are reported in Table S3. The GrI\% was evaluated at the four sampling times $(0,7,14$ and 28 days).

The GrI\% values of SIL and MON non-treated soils were very low (SIL: 2.09\%; MON: $1.71 \%$ ), showing both soils were unsuitable for plant growth. These results were ascribable to the very low organic carbon and nutrient content of the soil, which was collected at $50 \mathrm{~m}$ depth. However, adding the products to SIL soil not only caused no significant toxic effect, but in the cases of SIL + P2 and SIL + P3 + P4 the plant growth was initially slightly stimulated. In MON soil, adding the product resulted in a worsened stunted seedling growth.

The acute test (organism exposure period: $48 \mathrm{~h}$ ) with the earthworm E. fetida on elutriates showed that all samples had $0 \%$ mortality except for the soils treated with lime $(\mathrm{SIL}+\mathrm{L}$ and SIL $+\mathrm{L}+\mathrm{P} 3)$, in which the mortality was more than $70 \%$ (data not shown). These results were due to the high $\mathrm{pH}$ value $(>11)$ for the lime treatment which caused a toxic effect on this organism.

The chronic test with the same earthworm (28 days of organism exposure to soil) was performed using soil samples collected at days 0 and 7 (Figure 3). At both sampling times, SIL showed a negligible mortality; in fact all values were lower than the threshold value of $20 \%$ [59]. For this reason, the test was not performed at the subsequent sampling times. Moreover, no significant differences with the values for the un-treated SIL and OECD soils were found.

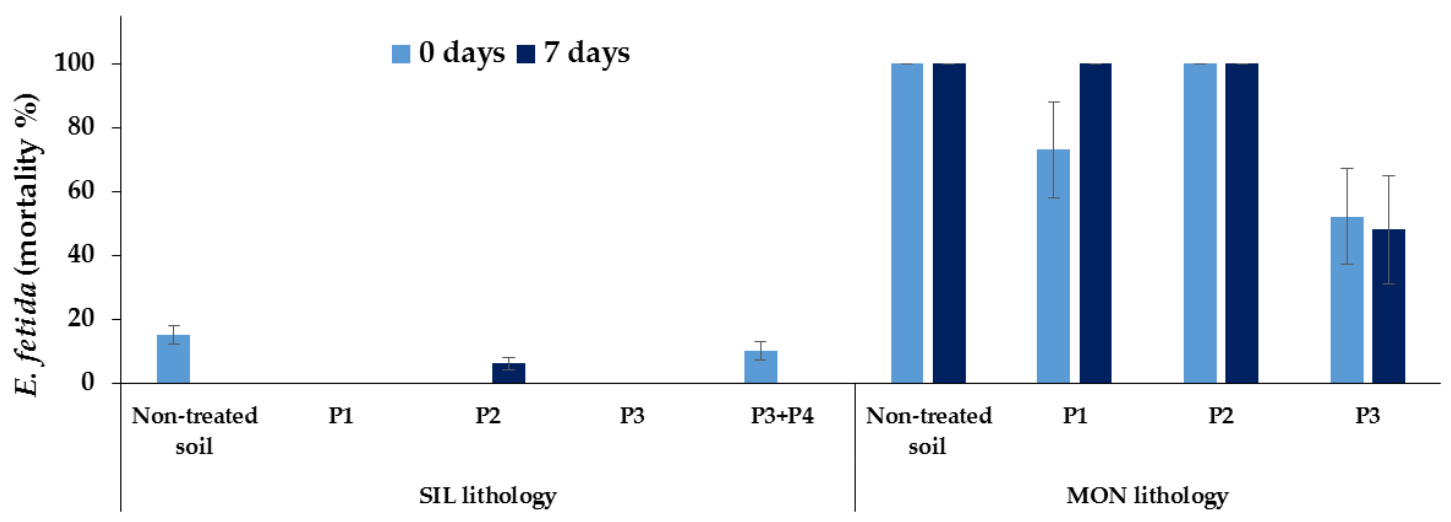

Figure 3. Chronic test (organism exposure period of 28 days) with the earthworm Eisenia fetida performed with soil samples at 0 and 7 days of the experiment. The results are expressed as mortality (\%) SIL: sandy-silty-clay soil; MON: gravel in a sandy-silty soil. P1, P2, P3, P4: foaming agent products. The vertical bars represent the standard errors.

As in the acute test results, lime was deleterious for worm survival; in fact, the soil treated with it (SIL + L and SIL + P3 + L) was highly toxic, causing $100 \%$ mortality for the organisms tested.

The chronic test of 28 days of exposure of the earthworm E. fetida to MON-conditioned $(\mathrm{MON}+\mathrm{P} 1, \mathrm{MON}+\mathrm{P} 2, \mathrm{MON}+\mathrm{P} 3)$ and un-treated soils showed a mortality higher than $20 \%$, with values between $50-100 \%$; the high mortality values were presumably due to the lithology (mainly composed of gravel) and a very low organic carbon content in its fine fraction, which caused worm death through starvation. Interestingly, a reduced mortality was found $(50 \% \pm 20 \%)$ in the MON $+\mathrm{P} 3$ condition.

Lastly, the results of the FET test ( $96 \mathrm{~h}$ exposure) performed with the embryo fish Danio rerio on elutriates from all soil mesocosms at the different experimental times $(0,7,14$ and 28 days) are reported in Figure 4A for SIL and 4B for MON, respectively. The mortality percentages for SIL (Figure 4A) were negligible; in fact, all values were lower than the $20 \%$ threshold and not significantly different from the untreated SIL soil. On the contrary, the MON soil conditioned with the products (Figure 4B) was toxic for Danio rerio (mortality 
$100 \%$ over the experimental time), whereas the un-treated MON soil showed mortality values lower than $20 \%$.
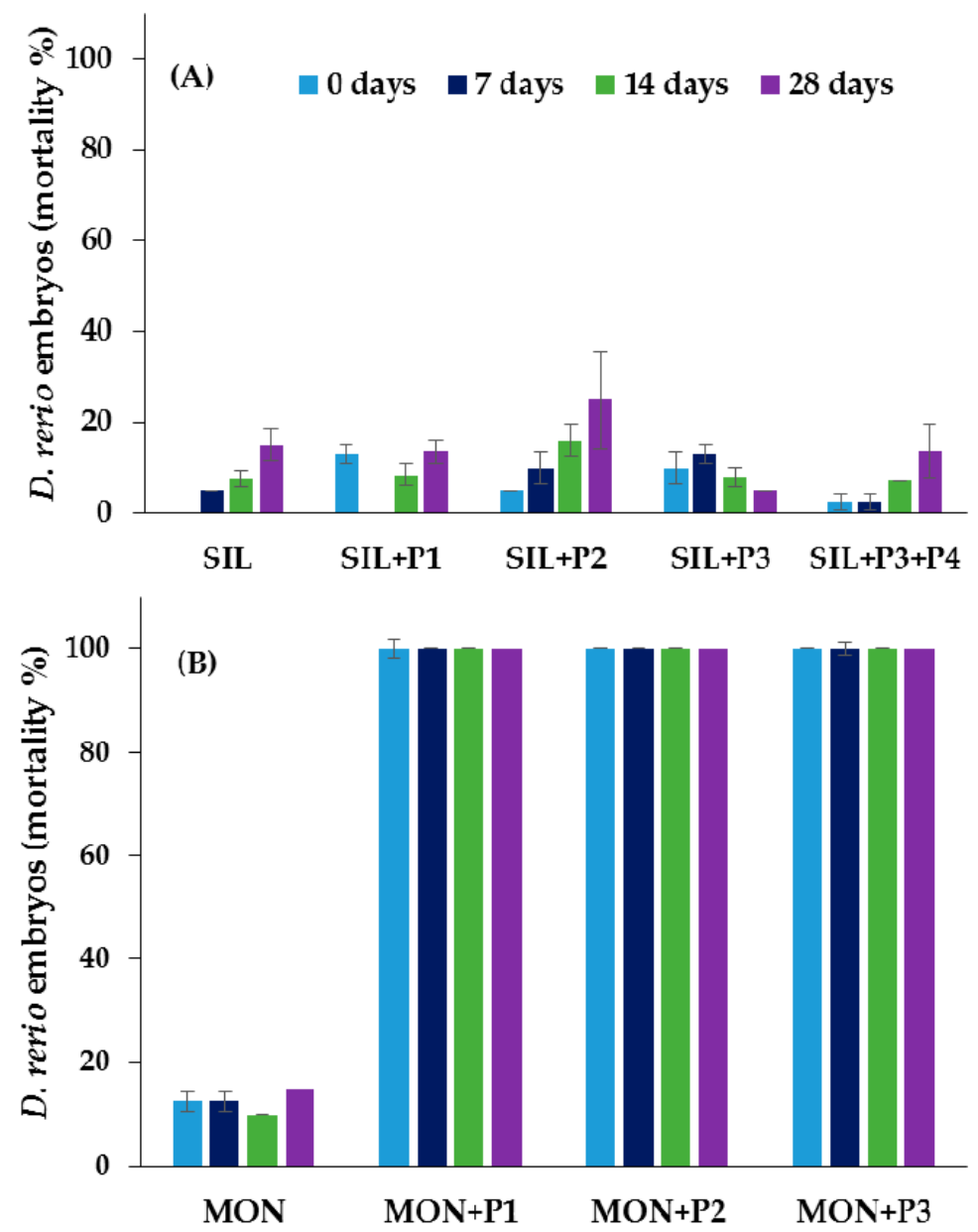

Figure 4. Fish Embryo Toxicity (FET) test at 96h of exposure of Danio rerio embryos to soil water extracts from (A) SIL and (B) and MON mesocosms. SIL: sandy-silty-clay soil; MON: gravel in a sandy-silty soil. P1, P2, P3, P4: foaming agent products.

In the case of the lime treatment, the $\mathrm{pH}$ of the elutriate was too high for embryo survival, so that it was not possible to perform the test because it does not foresee any $\mathrm{pH}$ correction in the OECD Guideline [48].

The results of the overall ecotoxicological tests of the foaming agent conditioned soils were integrated in a battery index. The results are reported in Figure 5A,B for SIL and $\mathrm{MON}$, respectively.

At day 0 the P3 soil mesocosms (SIL + P3 and SIL + P3 + Lime) showed the lowest toxicity index value $(<10 \%)$. Subsequently, the toxicity was lower for all SIL-conditioned soils, showing negligible risk battery index values.

As regards the MON-conditioned mesocosms, in all cases (MON + P1, MON + P2 and $\mathrm{MON}+\mathrm{P} 3$ ) the toxicity index values were higher than $30 \%$ (high toxicity). At 7 days the overall toxicity decreased only slightly, remaining quite high, except for P3 which was only just above $10 \%$. 


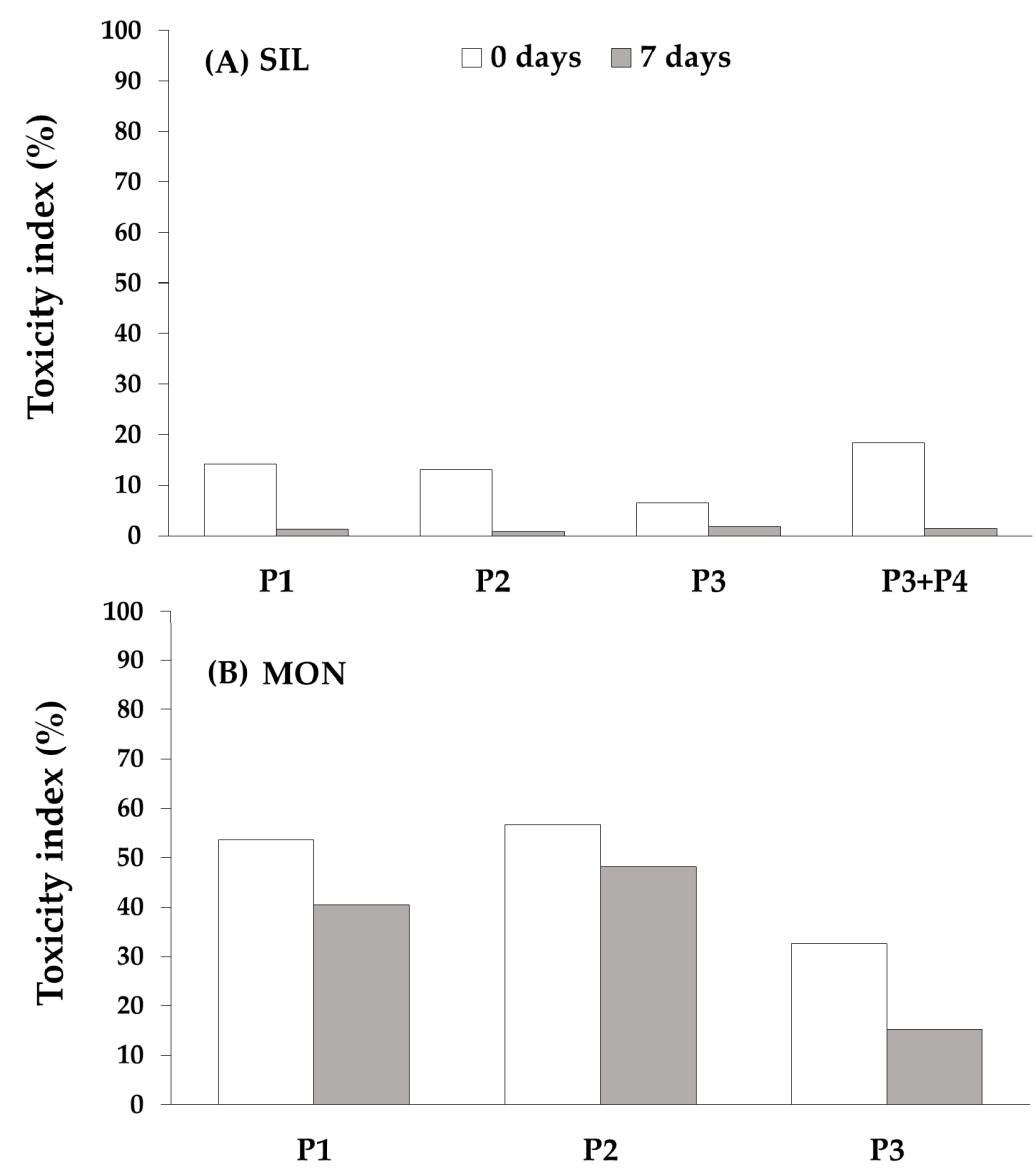

Figure 5. Integrated Toxicity index values at 0 and 7 days obtained from SIL (A) and MON (B) soil mesocosms treated with the various foaming agents. SIL: sandy-silty-clay soil; MON: gravel in a sandy-silty soil. P1, P2, P3, P4: foaming agent products.

\section{Discussion}

The current legislation at the national level for the re-use of spoil material as a byproduct (in industrial or green areas) establishes chemical thresholds for specific organic and inorganic contaminants (e.g., heavy metals, hydrocarbons with more than 12 carbon atoms; Italian Decrees No. 152/2006 and No. 120/2017) but there is no threshold at either the national or EU levels for anionic surfactants. In this study, the spoil material was analysed for all the contaminants regulated and it always met the legal requirements. However, for precautionary reasons the Italian Ministry of Environment required a sitespecific report demonstrating that the spoil material at the final destination site did not pose any risk for terrestrial or aquatic ecosystems. In this context, SLES occurrence in spoil material at concentrations affecting target soil and water organisms could be a risk for ecosystems.

The test results on terrestrial organisms (i.e., L. sativum and E. fetida) did not show SLES to be toxic, except for P1 at day 0 for plant germination (Table 4), where the highest SLES concentration was found. In line with these results a recent work [25] reported actual concentrations for the worm E. fetida of c.a. $300 \mathrm{mg}$ SLES $/ \mathrm{kg}$ soil, which were much higher than those found in this work. The results suggested that the foaming agents were not toxic for soil organisms at the concentrations used and are in line with those reported in similar studies $[45,60]$. Interestingly, adding lime was deleterious for the species tested, whether SLES was present or not. This was caused by a sharp soil $\mathrm{pH}$ increase and for this reason using lime at worksites is strongly advised against before the spoil material is classified as a by-product.

Regarding the water compartment, anionic surfactants can have a potential impact on aquatic organisms, which are known to be very sensitive to their residues $[17,25,28]$. 
For this reason, in this work we used the soil water extracts (elutriates) to check for a possible leaching of SLES from soil to water, following a standardized procedure (UNI EN 12457-2:2004) simulating this phenomenon.

The overall results suggest that the combination of each specific lithological characteristic of the soil (SIL or MON) and foaming agent applied (P1, P2, P3 and P4) influenced the persistence and partitioning of SLES between the soil and aqueous phase (elutriate) and consequently the toxicity, as found in other recent works $[17,25,45,60]$. In fact, SLES decreased over time only in the mesocosms containing SIL soil. This last lithology showed an organic carbon content $\left(0.5 \% \mathrm{OC}_{\mathrm{SIL}}>0.3 \% \mathrm{OC}_{\mathrm{MON}}\right)$, microbial abundance values (SIL: $2 \times 10^{6}$ cells/g soil $>$ MON: $5 \times 10^{4}$ cells/g soil) and a water holding capacity (Table S1) higher than MON. These parameters are recognized as key factors in SLES degradation $[23,60]$. Moreover, the soil lithologies not only influenced the anionic surfactant degradation, but also its leaching from soil to water. The SLES concentrations in the elutriate produced in the case of MON were found to be double those for SIL, both because the initial product concentrations in the soil were higher and because of the predominance of the gravel fraction in MON, which decreased its adsorption capacity. Finally, each foaming agent (P1, P2, P3 and P4) displayed a different environmental fate and toxicity, owing to its different formulation. Soil conditioned with P3 showed the lowest SLES concentrations both in soils and elutriates at the starting time (day 0). The $\mathrm{EC}_{20}$ and $\mathrm{EC}_{50}$ values obtained in the pre-screening tests conducted on the commercial products, using $V$. fischeri, showed P3 to be the most environmentally friendly and P4 the most toxic and this can explain why, when combined (P3 + P4), the SIL soil showed the highest overall toxicity (Figures 2 and 5). In fact, P3 was selected for use in the subsequent tunnelling.

Regarding the ecotoxicological tests, all the products, except P3, were initially toxic for the bacterium $V$. fischeri, confirming the direct sensitivity of this organism to SLES concentrations higher than $2 \mathrm{mg} / \mathrm{L}$ [16].

In the case of MON, the products were always toxic at the treatment ratios used in this work because, as mentioned above, this matrix showed a low water adsorption capacity and high amounts of SLES (from 9 to $23 \mathrm{mg} / \mathrm{L}$ ) moved from the solid phase to the aqueous elutriates, proving to be toxic for the aquatic organisms Vibrio fischeri and Danio rerio.

In order to summarize in a number the overall test results and to rank the foaming agent ecotoxicity in SIL and MON soils, a toxicity test battery integrated index was applied. The use of a set of biotests is a common practice when seeking an overview of toxicity [61-63]. It is interesting to note that the battery index applied was initially designed for the aquatic environment [55] and, for this reason, in this case reflects a highly precautionary scenario that takes into account any possible SLES leaching or run off to water bodies $[16,17,27]$.

The toxicity score obtained from the calculation of the battery index made it possible to highlight the $\mathrm{P} 3$ foaming agent as the most environmentally friendly one, in the case of both SIL and MON. The simultaneous application of P3 and P4 was the worst case for its potentially higher toxicity than the others (Figure 5A).

On the basis of the results reported above a site-specific Technical Report was performed and the P3 commercial product was proposed for the tunnel excavation. During the actual tunnelling phase, most of the soil excavated was a mix of SIL and MON lithologies and the TR applied sometimes lower; consequently, intermediate ecotoxicological and chemical results, rather than the extreme ones obtained from the mesocosm studies, were expected. To assess the environmental compatibility of the spoil material at the construction site during the tunnelling, the determination of the anionic surfactant SLES and the test with the bacterium $V$. fischeri in the aqueous phase were proposed as monitoring tools. In particular, a site-specific protocol was drawn up and then approved by the Italian authorities, as in previous works [24,64]. The Technical Report recognised $2 \mathrm{mg} / \mathrm{L}$ as a threshold value for SLES concentration in elutriates and a bioluminescence inhibition $\leq 20 \%$. If these conditions were met, the soil excavated could be used as a by-product; otherwise, it had to be kept at the temporary deposit construction site until these requirements were verified. It 
was implicit that this protocol also had to be in line with the legal framework for excavated material and the circular economy requirements (recovery of scrap material by producing less waste [65]).

The use of foaming agents in EPB-TBM technology is necessary and several companies have been working on new commercial products in order to increase their effectiveness and at the same time lower their potential environmental impact. This means that the chemical formulas of foaming agent products are continuously changing. The use of suitable ecotoxicological tests for evaluating foaming agents and excavated soils containing them should be foreseen by legislation in order to compensate for the lack of legal thresholds not only in Italy, but also at the European level, for tunnel excavation. In fact, the ecotoxicological tests have the enormous advantage of evaluating any possible toxic effects in a commercial product, whatever its composition.

\section{Conclusions}

The re-use of spoil material as a by-product from tunnelling with a TBM-EPB needs to be evaluated with ecotoxicological studies. Such studies are very useful for establishing the most environmentally friendly product and the period foam-conditioned soil should be stored in temporary deposit areas before its safe use. In this work, the ecotoxicological approach made it possible to define a site-specific technical report with appropriate operating procedures to be applied for monitoring spoil material over the tunnelling time. The tunnel excavation described here has just been completed using the P3 foaming agent (the intrinsically less ecotoxic product and with less toxicity index values in the mesocosm experiment) and the use of the Vibrio fischeri test as an ecotoxicological tool proved suitable for defining the environmental compatibility of the spoil material, thus making up for the lack of a SLES threshold in the current legislation.

Supplementary Materials: The following are available online at https:/ /www.mdpi.com/2073-4 441/13/2/161/s1, Table S1: Maximum Water Holding Capacity (WHCmax) and moisture of soils ( \pm e.s.) in the various mesocosms. P1, P2, P3 and P4: foaming agent products. SIL: sandy-silty-clay soil; MON: gravel in a sandy-silty soil. L: lime., Table S2: $\mathrm{pH}$ values of soil and water extracts for each condition and sampling time. P1, P2, P3 and P4: foaming agent products. SIL: sandy-silty-clay soil; MON: gravel in a sandy-silty soil. L: lime. Table S3: Lepidium sativum Growth index (GrI \%) and standard errors (s.e.) at 21 days of L. sativum plants grown in SIL or MON soils collected from mesocosms at $0,7,14$ and 28 days. P1, P2, P3 and P4: foaming agent products.SIL: sandy-silty-clay soil; MON: gravel in a sandy-silty soil. L: lime.

Author Contributions: Conceptualization, A.B.C. and P.G.; methodology, formal analysis and validation, A.B.C., P.G., L.M., J.R., M.D.L., V.G.M., E.D., I.L., P.M.B.G., A.F., E.B., L.P.; writing-original draft preparation, P.G., A.B.C., L.P., L.M.; writing-review and editing, P.G., A.B.C., supervision, A.B.C., P.G., L.P.; funding acquisition, A.B.C. All authors have read and agreed to the published version of the manuscript.

Funding: This work was funded by the Italian Company Autostrade Spa—Project No.1200167/2015.

Institutional Review Board Statement: Not applicable.

Informed Consent Statement: Not applicable.

Acknowledgments: The authors would like to thank Daniela Peila, Daniele Martinelli and Carmine Todaro of the Department of Environment, Land and Infrastructure Engineering (DIATI) at the Polytechnic University of Turin for their valuable scientific support in calculating the amount of foaming agent to add to soils (TRs) and in conditioning the soil samples. We also thank Rossella Degni, Environmental Impacts Monitoring Manager at the Autostrade Company for her competent and stimulating project coordination.

Conflicts of Interest: The authors declare no conflict of interest. 


\section{References}

1. EC. Communication from the Commission to the European Parliament, the Council, the European Economic and Social Committee and the Committee of the Regions. Closing the Loop_An EU Action Plan for the Circular Economy; COM(2015) 614 Final; European Commission: Brussels, Belgium, 2015; p. 21. Available online: https://eur-lex.europa.eu/legal-content/EN/TXT/PDF/?uri= CELEX:52015DC0614\&from $=$ EN (accessed on 10 November 2020).

2. EC. Environment Action Programme to 2020. European Commission. Available online: https://ec.europa.eu/environment/actionprogramme (accessed on 18 June 2019).

3. EC. Communication from the Commission to the European Parliament, the Council, the European Economic and Social Committee and the Committee of the Regions. A New Circular Economy Action Plan for a Cleaner and More Competitive Europe; COM(2020) 98 Final; European Commission: Brussels, Belgium, 2020; p. 20. Available online: https:/ / eur-lex.europa.eu/legal-content/EN/TXT/ PDF/?uri=CELEX:52020DC0098\&from=EN (accessed on 10 November 2020).

4. Entacher, M.; Resch, D.; Reichel, P.; Galler, R. Recycling of tunnel spoil-Laws affecting waste from mining and tunnelling/Wiederverwertung von Tunnelausbruchmaterial-Abfallrecht im Berg- und Tunnelbau. Geomech. Tunn. 2011, 4, 692-701. [CrossRef]

5. EU. Directive 2008/98/EC of the European Parliament and of the Council of 19 November 2008 on waste and repealing certain Directives (Text with EEA relevance). Off. J. Eur. Union 2008, 51, 312.

6. Oggeri, C.; Fenoglio, T.M. Muck classification: Raw material or waste in tunnelling operation. Rev. Min. 2014, 20, 16-25.

7. Oggeri, C.; Fenoglio, T.M.; Vinai, R. Tunnel spoil classification and applicability of lime addition in weak formations for muck reuse. Tunn. Undergr. Space Technol. 2014, 44, 97-107. [CrossRef]

8. Oggeri, C.; Fenoglio, T.M.; Vinai, R. Tunnelling Muck Classification: Definition and Application. In Proceedings of the World Tunnel Congress 2017-Surface Challenges—Underground Solutions, Bergen, Norway, 9-15 June 2017; pp. 1-10.

9. Magnusson, S.; Lundberg, K.; Svedberg, B.; Knutsson, S. Sustainable management of excavated soil and rock in urban areas-A literature review. J. Clean. Prod. 2015, 93, 18-25. [CrossRef]

10. Rahimzadeh, A.; Tang, W.; Sher, W.; Davis, P. Management of Excavated Material in Infrastructure Construction-A Critical Review of Literature. In Proceedings of the International Conference on Architecture and Civil Engineering, Sydney, Australia, 10-12 January 2018; pp. 1-7.

11. Voit, K.; Kuschel, E. Rock material recycling in tunnel engineering. Appl. Sci. 2020, 10, 2722. [CrossRef]

12. Bellopede, R.; Marini, P. Aggregates from tunnel muck treatments. Properties and uses. Physicochem. Probl. Miner. Process. 2011, 40, 259-266.

13. Thames Tideway Tunnel. Excavated Materials Options Assessment (EMOA). 2003; p. 408. Available online: https: / /infrastructure.planninginspectorate.gov.uk/wp-content/ipc/uploads/projects/WW010001/WW010001-003342-9.10.03 _Excavated_Materials_Options_Assessment_(EMOA)\%20_Annex_D9_to_D16.pdf (accessed on 13 January 2020).

14. D.P.R. 120/2017. Regulation on the simplified discipline of the excavated soil and rock management, pursuant to article 8 of the decree-law 12 September 2014, n. 133 (Decreto del Presidente della Repubblica 13 giugno 2017, n. 120. Regolamento recante la disciplina semplificata della gestione delle terre e rocce da scavo, ai sensi dell'articolo 8 del decreto-legge 12 settembre 2014 , n. 133, convertito, con modificazioni, dalla legge 11 novembre 2014, n. 164. In Italian). Gazz. Uff. Repubb. Ital. Ser. Gen. 2017, 183, 1-40. Available online: https://www.gazzettaufficiale.it/eli/gu/2017/08/07/183/sg/pdf (accessed on 13 January 2020).

15. D.M. 161/2012. Decree of the Ministry of the Environment and the Protection of the Territory and the Sea of 10 August 2012 , $n$. 161 Regulation regulating the use of excavated soil and rocks (Regolamento recante la disciplina dell'utilizzazione delle terre e rocce da scavo. In Italian). Gazz. Uff. Repubb. Ital. Ser. Gen. 2012, 221, 1-34. Available online: http:/ /www.arpa.fvg.it/export/ sites/default/tema/rifiuti/allegati/DM_161-12.pdf (accessed on 13 January 2020).

16. Mariani, L.; Grenni, P.; Barra Caracciolo, A.; Donati, E.; Rauseo, J.; Rolando, L.; Patrolecco, L. Toxic response of the bacterium Vibrio fischeri to sodium lauryl ether sulphate residues in excavated soils. Ecotoxicology 2020, 29, 815-824. [CrossRef]

17. Grenni, P.; Barra Caracciolo, A.; Patrolecco, L.; Ademollo, N.; Rauseo, J.; Saccà, M.; Mingazzini, M.; Palumbo, M.; Galli, E.; Muzzini, V.; et al. A bioassay battery for the ecotoxicity assessment of soils conditioned with two different commercial foaming products. Ecotoxicol. Environ. Saf. 2018, 148, 1067-1077. [CrossRef]

18. Peila, D. Soil conditioning for EPB shield tunnelling. KSCE J. Civ. Eng. 2014, 18, 831-836. [CrossRef]

19. Peila, D.; Martinelli, D.; Todaro, C.; Luciani, A. Soil conditioning in EPB shield tunnelling-An overview of laboratory tests. Géoméch. Tunnelbau 2019, 12, 491-498. [CrossRef]

20. Vinai, R.; Oggeri, C.; Peila, D. Soil conditioning of sand for EPB applications: A laboratory research. Tunn. Undergr. Space Technol. 2008, 23, 308-317. [CrossRef]

21. Peila, D.; Picchio, A.; Martinelli, D.; Negro, E.D. Laboratory tests on soil conditioning of clayey soil. Acta Geotech. 2016, 11, 1061-1074. [CrossRef]

22. Kim, T.H.; Kim, B.K.; Lee, K.H.; Lee, I.M. Soil conditioning of weathered granite soil used for EPB shield TBM: A laboratory scale study. KSCE J. Civ. Eng. 2019, 23, 1829-1838. [CrossRef]

23. Barra Caracciolo, A.; Ademollo, N.; Cardoni, M.; Di Giulio, A.; Grenni, P.; Pescatore, T.; Rauseo, J.; Patrolecco, L. Assessment of biodegradation of the anionic surfactant sodium lauryl ether sulphate used in two foaming agents for mechanized tunnelling excavation. J. Hazard. Mater. 2019, 365, 538-545. [CrossRef] [PubMed] 
24. Padulosi, S.; Martelli, F.; Sciotti, A.; Putzu, D.F.D.; Filippone, M.; Mininni, G.; Martelli, A.; Sciotti, A.; Putzu, D.F.D.; Filippone, M.; et al. Environmental risk assessment of conditioned soil: Some Italian case studies. In Tunnels and Underground Cities. Engineering and Innovation Meet Archaeology, Architecture and Art: Proceedings of the WTC 2019 ITA-AITES World Tunnel Congress (WTC, Naples, 3-9 May 2019); Peila, D., Viggiani, G., Celestino, T., Eds.; CRC Press: London, UK, 2019; pp. 505-514.

25. Finizio, A.; Patrolecco, L.; Grenni, P.; Galli, E.; Muzzini, V.; Rauseo, J.; Rizzi, C.; Barra Caracciolo, A. Environmental risk assessment of the anionic surfactant sodium lauryl ether sulphate in site-specific conditions arising from mechanized tunnelling. J. Hazard. Mater. 2020, 383, 121116. [CrossRef]

26. Rolando, L.; Grenni, P.; Rauseo, J.; Pescatore, T.; Patrolecco, L.; Garbini, G.L.; Visca, A.; Barra Caracciolo, A. Isolation and characterization in a soil conditioned with foaming agents of a bacterial consortium able to degrade sodium lauryl ether sulfate. Front. Microbiol. 2020, 11, 1542. [CrossRef]

27. Bakırel, T.; Keleş, O.; Karatas, S.; Özcan, M.; Türkmen, G.; Candan, A.; Bakırel, T.; Candan, A. Effect of linear alkylbenzene sulphonate (LAS) on non-specific defence mechanisms in rainbow trout (Oncorhynchus mykiss). Aquat. Toxicol. 2005, 71, 175-181. [CrossRef]

28. Barra Caracciolo, A.; Cardoni, M.; Pescatore, T.; Patrolecco, L. Characteristics and environmental fate of the anionic surfactant sodium lauryl ether sulphate (SLES) used as the main component in foaming agents for mechanized tunnelling. Environ. Pollut. 2017, 226, 94-103. [CrossRef] [PubMed]

29. Jardak, K.; Drogui, P.; Daghrir, R. Surfactants in aquatic and terrestrial environment: Occurrence, behavior, and treatment processes. Environ. Sci. Pollut. Res. 2016, 23, 3195-3216. [CrossRef]

30. Lechuga, M.; Fernández-Serrano, M.; Jurado, E.; Núñez-Olea, J.; Rios, F. Acute toxicity of anionic and non-ionic surfactants to aquatic organisms. Ecotoxicol. Environ. Saf. 2016, 125, 1-8. [CrossRef]

31. Liwarska-Bizukojc, E.; Miksch, K.; Malachowska-Jutsz, A.; Kalka, J. Acute toxicity and genotoxicity of five selected anionic and nonionic surfactants. Chemosphere 2005, 58, 1249-1253. [CrossRef] [PubMed]

32. ECHA. Alcohols, C12-14, Ethoxylated, Sulphates, Sodium Salts. European Chemicals Agency. Available online: https://echa. europa.eu/it/registration-dossier/- / registered-dossier/15887/6/1 (accessed on 13 January 2020).

33. Budach, C.; Thewes, M. Application ranges of EPB shields in coarse ground based on laboratory research. Tunn. Undergr. Space Technol. 2015, 50, 296-304. [CrossRef]

34. Peila, D.; Oggeri, C.; Vinai, R. Screw conveyor device for laboratory tests on conditioned soil for EPB tunneling operations. J. Geotech. Geoenviron. Eng. 2007, 133, 1622-1625. [CrossRef]

35. UNI EN 12457-2:2004. Characterisation of Waste-Leaching-Compliance Test for Leaching of Granular Waste Materials and Sludges-Part 2: One Stage Batch Test at a Liquid to Solid Ratio of 10 1/ kg for Materials with Particle Size Below 4 mm (Without or With Size Reduction). 2004, p. 30. Available online: http:/ /store.uni.com/catalogo/index.php/uni-en-12457-2-2004.html (accessed on 10 January 2020).

36. AWWA 5540 C. Anionic Surfactants as MBAS. In Standard Methods for the Examination of Water and Wastewater; Rice, E.W., Baird, R.B., Eaton, A.D., Eds.; American Water Works Association/American Public Works Association/Water Environment Federation; American Public Health Association: Washington, DC, USA, 2012; pp. 53-55.

37. Thompson, M.; Ellison, S.L.R.; Wood, R. Harmonized guidelines for single-laboratory validation of methods of analysis (IUPAC Technical Report). Pure Appl. Chem. 2002, 74, 835-855. [CrossRef]

38. Firouzei, Y.; Grenni, P.; Barra Caracciolo, A.; Patrolecco, L.; Todaro, C.; Martinelli, D.; Carigi, A.; Hajipour, G.; Hassanpour, J.; Peila, D. The most common laboratory procedures for the evaluation of EPB TBMs excavated material ecotoxicity in Italy: A review. GEAM Geoing. Ambient. Min. 2020, 2, 44-56.

39. UNI EN ISO 11348-3:2019. Water Quality—Determination of the Inhibitory Effect of Water Samples on the Light Emission of Vibrio Fischeri (Luminescent Bacteria Test)—Part 3: Method Using Freeze-Dried Bacteria. 2019, p. 44. Available online: http:/ / store.uni.com/catalogo/uni-en-iso-11348-3-2019 (accessed on 10 January 2020).

40. Persoone, G.; Marsalek, B.; Blinova, I.; Törökne, A.; Zarina, D.; Manusadzianas, L.; Nalecz-Jawecki, G.; Tofan, L.; Stepanova, N.; Tothova, L.; et al. A practical and user-friendly toxicity classification system with microbiotests for natural waters and wastewaters. Environ. Toxicol. 2003, 18, 395-402. [CrossRef]

41. Environment Canada. Guidance Document on Statistical Methods for Environmental Toxicity Tests; EPS 1/RM/46; Environmental Protection Series; Environmental Technology Centre, Environment Canada: Ottawa, ON, Canada, 2007; p. 283. Available online: http:/ / publications.gc.ca/site/eng/278313/publication.html (accessed on 10 January 2020).

42. US EPA. Ecological Effects Test Guidelines. OPPTS 850.4200, Seed Germination/Root Elongation Toxicity Test. Publication No. 96-154; US-EPA: Washington, DC, USA, 1996; p. 283.

43. APAT. Proposal of a Technical Guidance on Analysis Methods for Soil and Contaminated Sites. Use of Ecotoxicological and Biological Indicators (Proposta di Guida Tecnica su Metodi di Analisi per il Suolo e i Siti Contaminati. Utilizzo di Indicatori Biologici ed ecotossicologici; APAT, Agenzia per la Protezione dell'Ambiente e per i servizi Tecnici: Rome, Italy, 2004; p. 160. Available online: https:/ /www. isprambiente.gov.it/files/biodiversita/APAT_Guida_tecnica_indicatori_2004.pdf (accessed on 15 October 2019). (In Italian)

44. Luo, Y.; Liang, J.; Zeng, G.; Chen, M.; Mo, D.; Li, G.; Zhang, D. Seed germination test for toxicity evaluation of compost: Its roles, problems and prospects. Waste Manag. 2018, 71, 109-114. [CrossRef]

45. Galli, E.; Muzzini, V.G.; Finizio, A.; Fumagalli, P.; Grenni, P.; Barra Caracciolo, A.; Rauseo, J.; Patrolecco, L. Ecotoxicity of foaming agent conditioned soils tested on two terrestrial organisms. Environ. Eng. Manag. J. 2019, 18, 1703-1710. [CrossRef] 
46. OECD. Test No. 222: Earthworm Reproduction Test (Eisenia fetida/Eisenia Andrei); OECD Guidelines for the Testing of Chemicals, Section 2; OECD Publisher: Paris, France, 2016; p. 21.

47. OECD. Test No. 207: Earthworm, Acute Toxicity Tests; OECD Guidelines for the Testing of Chemicals, Section 2; OECD Publishing: Paris, France, 1984; p. 9.

48. OECD. Test No. 236: Fish Embryo Acute Toxicity (FET) Test; OECD Guidelines for the Testing of Chemicals, Section 2; OECD Publishing: Paris, France, 2013; p. 22.

49. Wernersson, A.-S.; Carere, M.; Maggi, C.; Tusil, P.; Soldan, P.; James, A.; Sanchez, W.; Dulio, V.; Broeg, K.; Reifferscheid, G.; et al. The European technical report on aquatic effect-based monitoring tools under the water framework directive. Environ. Sci. Eur. 2015, 27, 7. [CrossRef]

50. Cristiano, W.; Lacchetti, I.; Mancini, L.; Corti, M.; Di Domenico, K.; Di Paolo, C.; Hollert, H.; Carere, M. Promoting zebrafish embryo tool to identify the effects of chemicals in the context of Water Framework Directive monitoring and assessment. Microchem. J. 2019, 149, 104035. [CrossRef]

51. Lammer, E.; Carr, G.J.; Wendler, K.; Rawlings, J.M.; Belanger, S.E.; Braunbeck, T. Is the fish embryo toxicity test (FET) with the zebrafish (Danio rerio) a potential alternative for the fish acute toxicity test? Comp. Biochem. Physiol. Part C Toxicol. Pharmacol. 2009, 149, 196-209. [CrossRef]

52. Sobanska, M.A.; Scholz, S.; Nyman, A.-M.; Cesnaitis, R.; Alonso, S.G.; Klüver, N.; Kühne, R.; Tyle, H.; De Knecht, J.; Dang, Z.; et al. Applicability of the fish embryo acute toxicity (FET) test (OECD 236) in the regulatory context of Registration, Evaluation, Authorisation, and Restriction of Chemicals (REACH). Environ. Toxicol. Chem. 2018, 37, 657-670. [CrossRef]

53. Joint Research Centre. EURL ECVAM RECOMMENDATION on the Zebrafish Embryo Acute Toxicity Test Method (ZFET) for Acute Aquatic Toxicity Testing; European Commission, Joint Research Centre, Institute for Health and Consumer Protection: Ispra, Italy, 2014; p. 37. Available online: https://publications.jrc.ec.europa.eu/repository/bitstream/JRC91098/eur\%2026710_eurl\%20 ecvam\%20zfet\%20recommendation__online.pdf (accessed on 11 January 2019).

54. Busquet, F.; Strecker, R.; Rawlings, J.M.; Belanger, S.E.; Braunbeck, T.; Carr, G.J.; Cenijn, P.H.; Fochtman, P.; Gourmelon, A.; Hübler, N.; et al. OECD validation study to assess intra- and inter-laboratory reproducibility of the zebrafish embryo toxicity test for acute aquatic toxicity testing. Regul. Toxicol. Pharmacol. 2014, 69, 496-511. [CrossRef]

55. ISPRA. Ecotoxicological Bioassay Batteries for Sediments and Inland Waters (Batterie di Saggi Ecotossicologici per Sedimenti e Acque interne); ISPRA, Istituto Superiore per la Protezione e la Ricerca Ambientale, Manuali e linee guida 88/2013: Rome, Italy, 2013 ; p. 79. Available online: https:/ / www.isprambiente.gov.it/it/pubblicazioni/manuali-e-linee-guida/batterie-di-saggi-ecotossicologiciper-sedimenti-e-acque-interne (accessed on 15 July 2020).

56. Manzo, S.; Schiavo, S.; Aleksi, P.; Tabaku, A. Application of a toxicity test battery integrated index for a first screening of the ecotoxicological threat posed by ports and harbors in the southern Adriatic Sea (Italy). Environ. Monit. Assess. 2014, 186, 7127-7139. [CrossRef]

57. Hartwell, S.I. Demonstration of a toxicological risk ranking method to correlate measures of ambient toxicity and fish community diversity. Environ. Toxicol. Chem. 1997, 16, 361-371. [CrossRef]

58. OECD. Test No. 208: Terrestrial Plant Test: Seedling Emergence and Seedling Growth Test; OECD Guidelines for the Testing of Chemicals, Section 2; OECD Publishing: Paris, France, 2006; p. 21.

59. UNI EN ISO 11268-2:2015. Soil Quality-Effects of Pollutants on Earthworms—Part 2: Determination of Effects on Reproduction of Eisenia Fetida/Eisenia Andrei; 2015; p. 20. Available online: http://store.uni.com/catalogo/uni-en-iso-11268-2-2015 (accessed on 10 January 2020).

60. Patrolecco, L.; Pescatore, T.; Mariani, L.; Rolando, L.; Grenni, P.; Finizio, A.; Spataro, F.; Rauseo, J.; Ademollo, N.; Muzzini, V.G.; et al. Environmental fate and effects of foaming agents containing sodium lauryl ether sulphate in soil debris from mechanized tunneling. Water 2020, 12, 2074. [CrossRef]

61. Giannakis, I.; Emmanouil, C.; Mitrakas, M.; Manakou, V.; Kungolos, A. Chemical and ecotoxicological assessment of sludge-based biosolids used for corn field fertilization. Environ. Sci. Pollut. Res. 2020, 1-13. [CrossRef]

62. Malara, A.; Oleszczuk, P. Application of a battery of biotests for the determination of leachate toxicity to bacteria and invertebrates from sewage sludge-amended soil. Environ. Sci. Pollut. Res. 2012, 20, 3435-3446. [CrossRef] [PubMed]

63. Abreu-Junior, C.H.; de Lima Brossi, M.J.; Monteiro, R.T.; Silveira Cardoso, P.H.; da Silva Mandu, T.; Nogueira, T.H.R.; Ganga, A.; Filzmoser, P.; Oliveira, F.C.; Pittol Firme, L.; et al. Effects of sewage sludge application on unfertile tropical soils evaluated by multiple approaches: A field experiment in a commercial Eucalyptus plantation. Sci. Total Environ. 2019, 655, 1457-1467. [CrossRef] [PubMed]

64. Grenni, P.; Barra Caracciolo, A.; Patrolecco, L. Site-specific protocols for evaluating environmental compatibility of spoil materials produced by EPB-TBMs. In Tunnels and Underground Cities: Engineering and Innovation meet Archaeology, Architecture and Art; Peila, D., Viggiani, G., Celestino, T., Eds.; CRC Press: London, UK, 2019; pp. 360-366.

65. Garbarino, E.; Orveillon, G.; Saveyn, H.G.M.; Barthe, P.; Eder, P. Best Available Techniques (BAT) Reference Document for the Management of Waste from Extractive Industries, in Accordance with Directive 2006/21/EC; European Commission, Joint Research Centre, Directorate B-Growth and Innovation Circular Economy and Industrial Leadership; EUR 28963 EN; Publications Office of the European Union: Luxembourg, 2018; p. 72. Available online: https://op.europa.eu/it/publication-detail/-/publication/ 74b27c3c-0289-11e9-adde-01aa75ed71a1 (accessed on 10 January 2020). [CrossRef] 